DOI: 10.20472/IAC.2018.038.011

CESAR ESCALANTE

University of Georgia, United States

HOFNER RUSIANA

University of Georgia, United States

\title{
BORROWER-SPECIFIC AND INSTITUTIONAL FACTORS LEADING TO THE FORCED OR VOLUNTARY EXIT OF MICROFINANCE BORROWERS
}

\begin{abstract}
:
Microfinance borrowers tend to have no properties to offer as loan security (collateral) as they are poor and low-income, and thus would constitute a considerable risk to lenders once they default. MFIs, therefore, have to device a system to ensure that loan defaults are as low as possible in order to maintain their financial sustainability, without which they would resort to higher interest rates that would only defeat the original intent of their microfinance lending philosophy.

This paper seeks to identify factors that affect the voluntary exits or forced eviction of Philippine borrowers from microfinance lending networks focusing on indicators that are

(a) $[$ internal to the borrowers' personal circumstances and business operating environments; and

(b) $\square$ those that capture the microfinance institutions' loan delivery operations.
\end{abstract}

The analysis will analyze data compiled by the Social Enterprise Development Partnerships, Inc. (SEDPI) on micro-insurance borrowers in the Philippines from 2000 to 2010.

Econometric analysis will employ Heckman selection techniques to determine significant determinants of either the forced eviction or the voluntary exit of MFI borrowers. Two versions of the Heckman equation system will be developed. The first version defines the selection equation to select MFI borrower observations who were forced to leave the program (FORCED=1; VOLUNTARY $=0$ ) for the outcome equation that identifies significant factors behind such MFI action. The second version's selection equation focuses on the voluntary borrower exits (VOLUNTARY=1; FORCED $=0$ ) so that the outcome equation will determine significant factors behind such borrowers' decisions. Explanatory variables will capture personal, business, Centre-related, and macroeconomic factors.

Expected results will shed light on how sudden changes in personal circumstances of certain borrowers (physical and economic), business viability issues (often associated with macroeconomic conditions), and institutional factors affecting borrower servicing and other borrower-lender relationship issues may lead to either the MFIs' decision to evict certain borrowers or individual borrowers voluntarily deciding to exit from the MFI lending system.

This study offers important implications on achieving a proper balance of financial sustainability and social outreach goals of microfinance operations. This balancing of goals has been a difficult challenge for most MFIs globally. The Philippine microfinance experience may help shed light on possible remedies to this elusive balancing goal. 


\section{Keywords:}

microfinance, forced exit, voluntary exit, financial sustainability, loan repayment, loan delivery

JEL Classification: D19, G21, L26 